\title{
STRATEGI KOMUNIKASI HUMAS POLDA D. I. YOGYAKARTA MELALUI SKILL DIGITAL SAVVY DI ERA DISRUPTIF
}

\author{
Rahmat Hidayat Asri \\ Jurusan Ilmu Komunikasi, Fakultas Ilmu Sosial, Universitas Negeri Yogyakarta \\ Email : yoko.hidayat@gmail.com
}

\begin{abstract}
Abstrak. Tujuan penelitian ini adalah: (1) mengetahui mengenai strategi komunikasi Humas Polda D. I. Yogyakarta melalui skill digital savoy di era disruptif, (2) mengetahui kanal digital yang digunakan dalam strategi komunikasi Humas Polda D. I. Yogyakarta melalui skill digital savvy di era disruptif, (3) mengidentifikasi kelebihan dan kekurangan strategi komunikasi Humas Polda D. I. Yogyakarta melalui skill digital savoy di era disruptif. Penelitian ini merupakan penelitian deskriptif dengan pendekatan teknik kualitatif. Informan sebagai sumber data dalam penelitian ini yaitu Kepala Urusan Monitoring (Kaurmon) Bidang Humas Polda D. I. Yogyakarta. Metode pengumpulan data menggunakan metode wawancara, observasi, dan dokumentasi. Teknik keabsahan data ditentukan dengan menggunakan teknik triangulasi. Teknis analisis data menggunakan model interaktif Miles dan Huberman. Hasil penelitian menunjukkan bahwa strategi komunikasi humas Polda D. I. Yogyakarta melalui skill digital savoy di era disruptif yaitu: pengelolaan komunikasi Internal melalui WhatsApp sehingga pola komunikasi lebih sangkil dan mangkus, pelatihan pengelolaan media digital dengan materi yang fokus pada skill digital savvy, pengelolaan kanal digital yang aktif sebagai saluran komunikasi kepada publik, masyarakat dapat berkomunikasi secara langsung melalui media sosial, staf memiliki kemampuan yang lebih spesifik. Kanal digital yang digunakan yaitu facebook, twitter, instagram, channel youtube. Kelebihannya yaitu alur komunikasi humas Polda D. I. Yogyakarta menjadi lebih sangkil dan mangkus, penyajian informasi melalui kanal digital lebih terorganisir, menarik, masyarakat mudah terhubung dan memperoleh informasi, serta staf yang ada sesuai dengan bidangnya. Kekurangannya adalah kurangnya staf dan belum ada sub bidang multimedia yang memiliki fokus pada digital savvy.
\end{abstract}

Kata Kunci: strategi komunikasi, humas, digital savvy, era disruptif

Abstract. The objectives of this research are: (1) to know the communication strategy of the Yogyakarta Police Public Relations through digital savoy skill in the disruptive era, (2) to know digital channel used in the communication strategy of the Yogyakarta Police Public Relations through digital savoy skill in the disruptive era, (3) to identify the advantages and disadvantages of the communication strategy of the Yogyakarta Police Public Relations through digital savoy skill in the disruptive era. This research is a descriptive research with qualitative technique approach. Informant as the source of data in this research is The Head of Monitoring Affairs. The methods of data collection using interview, observation, and documentation. The technique of data validity is determined using triangulations technique. Technical analysis of data using interactive models by Miles and Huberman. The result of this research shows that the communication strategy of the Yogyakarta Police Public Relations through digital savoy skill in the disruptive era are: management of internal communication through WhatsApp so that communication pattern more effective and efficient, digital media management training with material focused on digital savoy skill, management of digital channels that are active as channels of communication to the public, the community can communicate directly through 
social media, staff have more specific capabilities. Digital channels used are facebook, twitter, instagram, youtube channel. The advantages of the communication channel the Yogyakarta Police Public Relations become more effective and efficient. Presentation of information through digital channels more organized, interesting, easy to connect and obtain information, as well as existing staff in accordance with their fields. The drawback is the lack of staff and no multimedia sub-sector that has a focus on digital savoy.

Keywords: communication strategy, public relations, digital savvy, disruptive era.

\section{Pendahuluan}

Seiring dengan kemajuan peradaban, masyarakat dihadapkan kepada situasi sosial yang dinamis. Situasi tersebut mengalami perubahan yang sangat signifikan. Seperti yang dikemukakan oleh Kartikasari (2017: 29) bahwa Saat ini, orang ramai membicarakan disruptive era. Era ketika banyak terjadi gangguan dan perubahan besar-besaran di segala bidang yang sebelumnya menikmati kemapanan. Hampir setiap bidang dan aspek kehidupan berubah. Bukan sekadar berubah, namun perubahannya begitu cepat dan membuat banyak orang pontang-panting untuk beradaptasi.

Istilah disruptif menjadi pembicaraan yang hangat di berbagai kalangan karena karakteristiknya yang sangat unik. Era yang membuat semua orang dengan mudahnya berbagi informasi dengan bebas. Karakteristik ini membuat paradigma baru yang tentunya sangat berbeda dengan paradigma lama. Disrupsi memasuki ruang lingkup dan scope kehidupan dalam bermasyarakat. Dalam hal ini, dahulu orang yang ingin mengetahui sebuah informasi yang sedang hangat dibicarakan, orang itu mencari sumber berita yang fisik dan lebih lengkap seperti membaca koran. Walaupun cara yang dilakukan memiliki kesan tradisional, lembar demi lembar dibuka untuk menemukan informasi hingga akhirnya mengetahui dari hulu ke hilir tentang isu yang sedang terjadi.

Berbeda dengan sekarang, era disrupsi mengubah kebiasaan hal tersebut. Orang yang awalnya mencari informasi melalui koran beralih ke era digital. Banyaknya portal berita online masa kini memudahkan publik menemukan informasi hanya dengan sentuhan di gawai (smartphone) yang dimiliki karena dianggap lebih sangkil (efektif) dan mangkus (efisien). Perilaku yang awalnya awam berangsur menjadi kebiasaan dan dapat ditolerir oleh masyarakat Indonesia. Bukan hanya dari mencari informasi, era disruptif merubah cara komunikasi masyarakat Indonesia. Era disruptif menjadikan penggunaan media digital semakin di depan, komunikasi melalui aplikasi di gawai menjadi kebiasaan sehari-hari. Laksamana (2018: 44) menjelaskan bahwa: “Dalam era disruptif ini, tidak ada lagi rahasia. Hidup kian menjadi digital. Banyak kegiatan kita, baik di tempat kerja maupun di rumah, dapat dilakukan secara online. Teknologi terus mendorong perubahan dengan semakin cepat".

Komunikasi melalui gawai benar-benar tidak mengenal ruang dan waktu. Perbedaan waktu dan tempat tidak menjadi penghalang dalam berkomunikasi saat ini. Beberapa tahun lalu, seseorang yang tinggal di Yogyakarta akan menghubungi teman yang berada di London, Inggris maka harus menyesuaikan waktu yang tepat. Perbedaan waktu 6 jam lebih cepat di Yogyakarta mengharuskan menunggu waktu yang tepat diantara keduanya agar sama-sama dalam kondisi fasilitas telepon ditambah biaya telepon internasional yang mahal. 
Saat ini, kapan dan dimana saja seseorang dapat melakukan komunikasi melalui gawainya. Banyak aplikasi yang bisa ditemukan pada gawainya. Kemudahan aplikasi yang tidak menghabiskan banyak biaya menjadikan seseorang berkomunikasi secara langsung baik melalui suara bahkan bertatap muka melalui video call. Penggunaan gawai memberikan kemudahan kepada penggunanya. Selain untuk berkomunikasi, gawai juga digunakan untuk membentuk diri di sosial media.

Perilaku bermedia sosial juga mengalami perubahan dan terdisruptif. Banyak orang memiliki sifat yang baik dan menjadi berbeda ketika berada di media sosial begitupun sebaliknya, publik bebas membentuk versi dirinya. Peningkatan jumlah pengguna media sosial semakin meningkat tiap tahunnya. Peningkatan pengguna media sosial menciptakan sebuah ruang baru, yaitu cyberspace. Andriadi (2016: 117) mengemukakan dengan sebuah metafora bahwa "Cyberspace adalah tempat dimana kita berada ketika kita mengarungi dunia informasi global interaktif yang bernama internet".

Kehadiran cyberspace dari dunia digital yang merupakan bagian dari era disruptif membuat seseorang yang awalnya biasa bisa menjadi sesuatu di media sosial. Andriadi (2016: 123) menjelaskan mengenai sensasi berada dalam cyberspace bahwa Seseorang bisa mengalami perasaan men-diri (sense of the self). Multi User Dungeon (MUD) adalah salah satu tempat di dalam cyberspace bagi setiap orang untuk memainkan peran dirinya dalam sebuah drama kolektif. Di dunia maya, setiap orang dibiarkan tetap menjadi dirinya. Agar ia merasa ada di dalam dunia natural. Ketika ia masuk ke cyberspace, orang dibuat merasa dirinya "ada", meski sebenarnya ia "tidak ada", karena hanya rekayasa.

Era disruptif membuat sebuah ruang baru yang publiknya bisa menjadi apa saja dan bisa mengeluarkan statement negatif maupun positif. Karena di cyberspace yang menjadi gatekeeper (penyaring informasi) adalah orang yang mengeluarkan statement itu sendiri. Dari hal itu, siapapun mampu menciptakan dirinya sendiri, termasuk seseorang dapat membuat identitas baru di media sosial yang berbeda dengan dirinya di dunia nyata.

Ruang yang membuat fungsi sebuah tools berubah, seperti halnya media sosial menjadi tempat untuk mencari tahu segalanya. Padahal, media sosial khususnya pada internet awalnya difungsikan untuk menghubungkan publik yang berbeda tempat, saat ini berubah fungsi sebagai media untuk informasi maupun entertainment. Media konvensial seperti koran, majalah dan media cetak lainnya mulai banyak ditinggal oleh pembacanya karena banyaknya informasi yang didapatkan dari media sosial.

Ketika ada peristiwa yang terjadi di lapangan, media konvensional harus mengambil informasi lalu mengumpulkan berita untuk dirapatkan bersama redaktur. Hingga akhirnya disetujui dan di cetak dalam koran di hari kemudian sehingga bisa sampai ke masyarakat. Di media sosial, akan sangat berbeda karena orang-orang mampu dengan realtime mengabarkan peristiwa saat itu juga bahkan hitungan detik ratusan bahkan ribuan orang mendapatkan informasi tersebut. Kemampuan media sosial yang lebih realtime membuat publik lebih percaya dengan informasi di media sosial.

Padahal, dari kebebasan memberikan konten, dan mengeluarkan pendapat di era disruptif ini, banyak informasi yang tidak terjamin kevaliditasannya (hoax). Beberapa oknum menggunakan kesempatan kebebasan di cyberspace tadi sebagai ajang 
untuk memberikan bahkan menyebarkan hoax karena adanya kepentingan atau untuk mencari perhatian serta membuat kehebohan semata. Dalam membuat informasi hoax, oknum pembuat hoax tersebut seringnya menggunakan nama instansi sebagai yang mengeluarkan berita hoax tersebut karena masyarakat lebih mudah percaya jika ada nama instansi tertentu.

Masyarakat Yogyakarta tentunya sering mendapatkan berita hoax mengenai kehidupan yang ada di kehidupan sehari-hari. Ditambah dengan mengambil nama instansi pemerintah yaitu salah satunya instansi kepolisian. Sama halnya yang dapatkan oleh Divisi Humas Kepolisian Daerah Istimewa Yogyakarta atau yang dikenal oleh masyarakat dengan sebutan Polda D. I. Yogyakarta pada 11 januari 2018 lalu melalui akun media sosial instagram resminya tentang berita hoax mengenai adanya razia zebra gabungan dengan polres dan polsek seluruh Indonesia lengkap dengan tanggal dan harinya. Padahal, informasi tersebut tidak valid dan banyak masyarakat yang percaya.

Selain itu, muncul juga berita hoax melalui pesan berantai dan di muat di media sosial instagram resmi Polda D. I. Yogyakarta mengenai Razia Surat Tanda Nomor Kendaraan Bermotor (STNK) yang mendapatkan denda sampai Rp. 400.000,00 dan berita ini membuat masyarakat percaya sehingga menimbukan pertanyaan melalui media sosial Polda D. I. Yogyakarta.

Polda D. I. Yogyakarta sebagai instansi yang dipercaya oleh masyarakat juga mengalami dampak dari era disruptif. Berdasarkan program prioritas yang dikutip dari polri.go.id, yaitu PROMOTER singkatan dari Profesional, Modern, Terpercaya yang dimiliki oleh Kepolisian Republik Indonesia (POLRI) dan diterapkan oleh Polda diseluruh Indonesia. Program ini menjadi pegangan kepada institusi kepolisian dalam meningkatkan pelayan kepada masyarakat, dimana peningkatan yang dilakukan dari berbagai macam aspek termasuk pada penggunaan teknologi yang lebih modern.

Hal ini sudah menjadi salah satu tugas Polda D. I. Yogyakarta untuk memberikan informasi yang transparan dan terbuka kepada masyarakat. Informasi yang disampaikan tentunya merupakan informasi yang terpercaya dan telah di check kevaliditasnya sehingga pesan yang disampaikan oleh masyarakat dapat diterima dengan baik.

Polda D. I. Yogyakarta melalui Divisi Humas (Hubungan Masyarakat) secara langsung terjun ke masyarakat untuk memberikan informasi mengenai kegiatan Polda D. I. Yogyakarta termasuk mengklarifikasi berita hoax yang menyangkut nama instansi kepolisian Polda D. I. Yogyakarta. Divisi Humas memiliki tanggungjawab besar terkait komunikasi secara langsung dengan masyarakat. Pada masa lampau, divisi humas hanya memilih media konvensional untuk menyiarkan segala aktivitasnya, baik menggunakan press release yang disebarkan kepada media maupun melakukan siaran pers dengan mengundang rekan media untuk meliput secara langsung mengenai peristiwa yang diangkat. Namun, saat ini cara tersebut termasuk dalam cara konvensional sehingga informasi yang disampaikan tidak sampai kepada beberapa kalangan masyarakat khususnya yang biasa menggunakan gawai untuk mencari informasi.

Instansi Polda D. I. Yogyakarta juga terdisrupsi sehingga membutuhkan inovasi untuk beradaptasi di era digital saat ini. Kartikasari (2017: 6-7) menjelaskan bahwa semakin kuatnya pengaruh teknologi digital dalam kehidupan sehari-hari telah 
mengubah cara berkomunikasi masyarakat. Tak terkecuali dunia kehumasan, pada akhirnya terdampak untuk memacu kreativitas serta berinovasi agar komunikasi dengan masyarakat terjalin secara efektif dan berdampak. Kita harus mengerti di kanal media sosial dan digital mana konsumen berada.

Humas Polda D. I. Yogyakarta, tidak mungkin untuk bertahan pada paradigma lama dengan hanya memanfaatkan siaran pers dan penyebaran press release yang terkesan tradisional di dunia kehumasan saat ini. Digitalisasi yang menjadi bagian dari era disrupsi juga harus dikuasai oleh humas agar mampu mengikuti kemauan masyarakat. Berbagai macam tools digital yang digunakan masyarakat juga harus dikuasai agar informasi yang disampaikan dapat diterima dengan baik.

Kepekaan terhadap perubahan merupakan salah satu sifat yang dimiliki oleh humas termasuk humas di instansi Polda D. I. Yogyakarta. Dalam hal beradaptasi di era disrupsi, humas mulai memiliki kemampuan untuk mengelola dan menggunakan teknologi digital dengan baik secara maksimal atau yang biasa disebut dengan istilah skill digital savoy. kemampuan dan keahlian atau dalam mengelola digital atau skill digital savvy secara langsung mempengaruhi pola komunikasi Humas Polda D. I. Yogyakarta. Hal ini menjadikan skill digital savoy sebagai strategi humas Humas Polda D. I. Yogyakarta dalam berkomunikasi secara langsung dengan masyarakat.

Ketika sebuah informasi hoax tersebar, Humas Polda D. I. Yogyakarta secara tanggap mengklarifikasi melalui salah satu kanal sosial medianya yaitu instagram. Untuk mengklarifikasi, Humas Polda D. I. Yogyakarta menyiapkan berbagai macam data dan konten agar informasi yang disampaikan dapat diterima oleh masyarakat. Bahasa dan konten yang digunakan juga menyesuaikan dengan kalangan masyarakat yang menggunakan kanal media sosial instagram sehingga citra Polda D. I. Yogyakarta terkesan fleksibel dan tidak kaku. Era disrupsi mempengaruhi media, termasuk lingkup humas, seperti yang dikemukakan Laksamana (2018: 45) bahwa dunia digital telah mendisrupsi dunia media. Otomatis juga berdampak pada profesi humas. Sepuluh tahun lalu, PR hanya perlu memperhatikan media tradisional. Kini, humas harus memonitor dan menganalisis semua channel, mulai dari Twitter, LinkedIn, Youtube, Facebook, LINE TODAY, hingga grup WhatsApp. Jumlah media online pun terus bertambah.

Penggunaan media sosial instagram sangat mangkus bagi Humas Polda D. I. Yogyakarta karena segala informasi dan klarifikasi dapat disiarkan langsung secara real time. Penggunaan kata-kata yang ditampilkan merepresentasikan institusi yang sangat bersahabat karena mengikuti bahasa millennial yang menjadi mayoritas followers akun Humas Polda D. I. Yogyakarta. Hal ini terlihat dari jumlah followers akun Humas Polda D. I. Yogyakarta yang meningkat secara signifikan dalam waktu yang singkat.

Begitu juga jika ada kendala atau keluhan yang terjadi di masyarakat, melalui twitter dimana keluhan yang disampaikan secara cepat diterima oleh tim Humas Polda D. I. Yogyakarta. Media sosial twitter dikenal sebagai media sosial yang khusus untuk melayani keluhan karena kecepatan dan kemudahan dalam berbalas pesan. Keluhan dari masyarakat yang diterima oleh Humas Polda D. I. Yogyakarta secara cepat diketahui dan tim merespon secara cepat terkait keluhan tersebut untuk kemudian dikoordinasikan oleh divisi terkait. Hal tersebut juga dilakukan Humas Polda D. I. Yogyakarta dalam menyebarkan informasi melalui facebook, karena media sosial ini dianggap sebagai media sosial dengan pengguna aktif yang banyak. 
Segala informasi mengenai berita dan kegiatan Polda D. I. Yogyakarta disampaikan bukan hanya melalui kanal media sosial. Humas Polda D. I. Yogyakarta juga menyediakan web resmi dengan informasi yang dibutuhkan oleh masyarakat sehingga masyarakat secara bebas dapat mengaksesnya. Banyaknya kanal digital yang digunakan dan diolah oleh Humas Polda D. I. Yogyakarta mengharuskan skill digital savoy bagi tim humas dalam menyiapkan konten yang akan disampaikan agar sesuai dengan kalangan setiap pengguna kanal digital yang digunakan.

Inovasi yang dilakukan oleh Humas Polda D. I. Yogyakarta mempermudah komunikasi antara Polda D. I. Yogyakarta dengan masyarakat agar tidak terjadi sekat dan mampu mendekatkan instansi kepolisian dengan masyarakat. Dari hal diatas, penulis ingin meneliti secara langsung mengenai bagaimana skill digital savoy digunakan oleh Humas Polda D. I. Yogyakarta sebagai strategi komunikasi dalam beradaptasi di era disruptif. Hal ini di karenakan banyaknya perubahan yang terjadi di setiap scope masyarakat yang mengharuskan adanya perubahan pada cara komunikasi institusi termasuk Humas Polda D. I. Yogyakarta.

\section{Metodologi}

\section{Pendekatan Penelitian}

Penelitian ini merupakan penelitian deskriptif dengan pendekatan kualitatif. Menurut Denzin dan Lincoln dalam Ahmadi (2016: 14), kata kualitatif menyatakan penekanan pada proses dan makna yang tidak diuji, atau diukur dengan setepattepatnya, dalam istilah-istilah kuantitas, jumlah, intensitas, atau frekuensi. Dalam penelitian kualitatif, peneliti mengkaji segala sesuatu dalam latar alamiahnya, untuk kemudian memahami dan menginterpretasi fenomena dalam hal makna-makna yang orang-orang berikan pada fenomena tersebut.

Cresswell dalam Ahmadi (2016: 15), mengemukakan bahwa penelitian kualitatif merupakan suatu proses inkuiri untuk pemahaman berdasarkan tradisitradisi inkuiri metodologis yang jelas yang mengeksplorasi masalah sosial dan manusia. Dalam pengertian tersebut, menggambarkan mengenai masalah yang diteliti dengan menggunakan penelitian kualitatif merupakan masalah sosial dan manusia.

Berdasarkan dua pengertian tentang penelitian kualitatif diatas, maka disimpulkan bahwa penelitian kualitatif merupakan penelitian untuk memahami situasi atau fenomena sosial dan manusia yang sedang terjadi secara alamiah (natural), apa adanya serta tanpa menggunakan pengukuran yang setepat-tepatnya. Pada proses analisis datanya pun tanpa menggunakan statistik.Metode dalam penelitian ini ialah metode deskriptif. Sugiyono (2014: 35), mengemukakan bahwa: "Penelitian deskriptif lebih kepada penjelasan variabel mandiri, bagaimana penelitian ini berkenaan dengan satu variabel atau lebih secara mandiri (dengan membandingkan masalah komparatif dan assosiatif)." Metode deskriptif ini menitikberatkan pada observasi dan suasana alamiah secara apa adanya, dengan peneliti bertindak sebagai pengamat.

Oleh karena itu, penelitian deskriptif dengan metode kualitatif yaitu penelitian yang digunakan dalam memahami situasi atau fenomena sosial dan manusia yang sedang terjadi secara apa adanya, dimana peneliti bertindak sebagai pengamat. Setelah mengamati, penelitian kualitatif dengan metode deskriptif mengharuskan peneliti menjabarkan hasilnya dan memadukan hasil yang diperoleh tersebut. Situasi atau 
fenomena sosial yang dimaksud dalam penelitian ini adalah penggunaan skill digital savvy di era disruptif dalam strategi komunikasi Humas Polda D. I. Yogyakarta.

\section{Setting Penelitian}

Penelitian dengan judul "Strategi Komunikasi Humas Polda D. I. Yogyakarta melalui Skill Digital Savvy di Era Disruptif", dilaksanakan di divisi Humas Polda D. I. Yogyakarta. Beralamat di jalan Lingkar Utara / Jalan Padjajaran, Condong Catur, Depok, Sleman, Daerah Istimewa Yogyakarta. Pada tanggal 20 April - 31 Mei 2018.

\section{Sumber Data}

Data merupakan bahan yang selalu ada didalam penelitian. Ahmadi (2016: 107) menjelaskan bahwa istilah data sering digunakan dalam makna tunggal (singular) atau jamak (plural). Dimana data ini merupakan apa yang dikatakan oleh narasumber yang diajukan seperangkat pertanyaan oleh peneliti. Lebih konkretnya, Patton dalam Ahmadi (2016: 108) mengemukakan bahwa sumber data dalam penelitian kualitatif adalah perkataan yang diperoleh secara verbal melalui wawancara atau dalam bentuk tertulis melalui analisis dokumen, atau respons survey. Karena pada dasarnya data kualitatif itu terdiri atas petikan-petikan dari orang-orang dan deskripsi tentang situasi, peristiwa, interaksi, dan peristiwa sehingga tujuan dan data ini untuk memahami sudut pandang pengalaman orang lain.

Sumber data primer didapatkan dari wawancara. Informan sebagai sumber data primer yang dipilih adalah Kepala Urusan Monitoring (Urmon) serta pegawai yang mengelola kanal digital Poda D. I. Yogyakarta. Informan tersebut dipilih berdasarkan Teknik purposive. Teknik ini menggunakan keputusan (judgment) ahli dalam memilih informan yang memiliki pengetahuan yang dibutuhkan dan terlibat langsung secara aktif dalam kasus yang akan diteliti. Ahmadi (2016: 86) mendreskripsikan mengenai pursposive yang dimaksud untuk menentukan informaninforman yang memang mewakili sejumlah informasi yang dibutuhkan dalam penelititan. Biasanya, orang-orang yang menjadi pelaku peristiwa adalah orang yang memiliki banyak pengalaman lebih banyak dan hal ini dipilih untuk merepresentasikan mengenai suatu kasus yang diteliti.

Sumber data sekunder didapatkan dari dokumentasi dan observasi. Dalam hal ini dokumentasi yang diperoleh berasal dari data-data yang digunakan dan berhubungan dengan kasus pada penelitian yang akan di laksanakan. Sedangkan observasi yang dilakukan yaitu observasi partisipan dengan terjun secara langsung untuk merasakan bagaimana kegiatan yang berhubungan dengan tema penelitian. Jadi peneliti mengambil dokumentasi dan berpartisipasi secara langsung di Subbidang Pengelolaan Informasi dan Dokumentasi (Subbid PID) yang merupakan bagian dari Bidang Hubungan Masyarakat (Bidhumas) Polda D. I. Yogyakarta termasuk dibawahnya, Kepala Urusan Pengumpulan dan Pengolahan Informasi dan Dokumentasi (Urpullahinfodok), Kepala Urusan Peliputan, Produksi, dan Dokumentasi (Urlipprodok), dan Kepala Urusan Monitoring (Urmon) serta berkomunikasi dengan pegawai yang mengelola kanal digital Poda D. I. Yogyakarta.

\section{Metode dan Instrumen Pengumpulan Data}

Penelitian dengan judul "Strategi Komunikasi Humas Polda D. I. Yogyakarta melalui Skill Digital Savoy di Era Disruptif" menggunakan 3 metode penelitian yaitu wawancara, observasi, dan dokumentasi. 
Dalam penelitian kualitatif, wawancara merupakan metode yang sangat berperan penting. Maykut dalam Ahmadi (2016: 119) menjelaskan bahwa dalam kajian-kajian kualitatif, wawancara sering berperan penting sewaktu peneliti berperan sebagai pengamat partisipan, meskipun orang-orang di tempat latar tidak menyadari bahwa percakapan informal tersebut adalah wawancara. Sama halnya yang dikemukaan oleh Patton dalam Ahmadi (2016: 119) menambahkan bahwa cara utama yang dilakukan oleh para ahli metodologi kualitatif untuk memahami persepsi, perasaan, dan pengetahuan orang-orang yang terlibat di tempat peneliti adalah wawancara mendalam dan intensif. Pada metode wawancara dalam penelitian ini, peneliti menggunakan 2 teknik wawancara, terstruktur dan tidak terstruktur.

Observasi merupakan teknik untuk menemukan informasi dalam penelitian. Ahmadi (2016: 161) menjelaskan bahwa observasi merupakan teknik pegumpulan data yang digunakan untuk memperoleh informasi atau data sebagaimana tujuan penelitian. Hadi dalam Sugiyono (2014: 145) menambahkan bahwa observasi merupakan proses yang kompleks, suatu proses yang tersusun dari pelbagai proses biologis dan psikologis dimana dua diantaranya merupakan proses pengamatan dan ingatan. Pada penelitian ini, peneliti menggunakan teknik observasi partisipasi. Bodgan dan Taylor dalam Ahmadi (2016: 163) mendefiniskan observasi partisipasi sebagai suatu periode interaksi sosial yang intensif antara peneliti dan subjek dalam lingkungan penelitian. Hal ini digunakan untuk mengetahui secara langsung mengenai apa yang terjadi di lapangan. Observasi partisipasi yang digunakan yaitu partisipasi pasif, dimana peneliti secara langsung mengamati perisitiwa yang terjadi dengan jarak dekat. Terdapat peraturan yang membuat peneliti tidak di ijinkan untuk terlibat secara aktif dalam kegiatan. Maka dari itu, observasi partisipasi pasif digunakan.

Teknik dokumentasi digunakan untuk mendapatkan bahan sebagai tambahan dalam pengumpulan data. Bogdan dan Biklen dalam Ahmadi (2016: 179) menjelaskan bahwa Pengertian dokumen dalam di sini adalah mengacu pada material (bahan) seperti fotografi, video, film, memo, surat, diari, rekaman kasus klinis, dan sejenisnya yang dapat digunakan sebagai informasi suplemen sebagai bagian dari kajian kasus yang sumber data utamanya adalah observasi partisipasi atau wawancara.

Dokumentasi yang digunakan oleh peneliti yaitu dokumen pribadi yang dimiliki oleh instansi yang akan diteliti, baik berupa laporan cetak maupun laporan digital yang seusai dengan tema penelitian.Dokumentasi melalui informasi diagram yang mengakses semua kanal digital yang dapat dijadikan sebagai sumber data karena berbagai macam perkembangan yang ada pada kanal digital Polda D. I. Yogyakarta yang dikelola oleh bidang Humas dapat memberikan informasi yang real.

Untuk instrumen dalam penelitian ini, yaitu manusia atau peneliti itu sendiri karena manusia yang mampu menjelaskan sebuah data dalam penelitian Ahmadi (2016: 103) menjelaskan bahwa dalam penelitian kualitatif, instrumen penelitian adalah manusia, yakni peneliti itu sendiri atau orang lain yang terlatih. Data yang akan diperoleh dalam penelitian kualitatif berupa kata-kata (Bahasa), tindakan, atau bahkan isyarat atau lambing. Untuk dapat menangkap atau menjelaskan data yang demikian, yang paling tepat sebagai instrument adalah manusia. 
Peneliti dijadikan sebagai instrumen karena penelitian kualitatif digunakan untuk mengembangkan wawasan manusia. Selain itu, manusia juga memiliki karakteristik yang mampu menjelaskan kevalidasian sebuah data.

\section{Keabsahan Data}

Data dalam penelitian yang telah diperoleh di lapangan tentunya harus diuji keabsahannya. Sugiyono (2014: 267) menjelaskan bahwa kriteria utama dalam data dari hasil penelitian kualitatif adalah valid, reliabel, dan objektif. Dimana validitas ini merupakan derajat ketepatan antara data yang terjadi pada objek penelitian dengan daya yang dapat dilaporkan oleh peneliti. Sehingga dapat dikatakan bahwa data yang valid adalah data yang tidak berbeda antara data yang di laporkan oleh peneliti dengan data yang sesungguhnya terjadi pada objek penelitian di lapangan.

Untuk menentukan keabsahan data yang diperoleh di lapangan, peneliti menggunakan triangulasi. Wiersma dalam Sugiyono (2014: 273) mendefinisikan bahwa "Triangulations is qualitative cross-validation. It assesses the sufficiency of the data according to the convergence of multiple data sources or multiple data collection procedures". Dalam hal ini penjelasan Wiersma dalam Sugiyono memaparkan bahwa triangulasi merupakan Teknik pengecekan data yang didapatkan dari berbagai macam sumber baik cara maupun waktu.

Teknik triangulasi yang digunakan oleh peneliti adalah triangulasi Teknik pengumpulan data. Sugiyono (2014: 274) menjelaskan bahwa triangulasi Teknik untuk menguji kredibilitas atau keabsahan data dilakukan dengan cara pengecekan data kepada semua sumber yang sama dengan teknik yang berbeda. Peneliti menggunakan wawancara sebagai sumber data primer lalu di check dengan observasi dan dokumentasi yang peneliti gunakan sebagai sumber data sekunder.

Hal ini dilakukan untuk menguji data dengan tiga sudut pandang yang diperoleh dari teknik pengumpulan data yang diperoleh. Peneliti menggunakan datadata yang ada yang melalui wawancara dengan subjek yang telah ditentukan lalu mencocokkan dengan dokumentasi yang diperoleh baik dari kanal digital maupun kegiatan yang di dapatkan melalui foto. Selanjutnya dengan observasi partisipasi pasif dengan melihat secara langsung objek penelitian menggunakan skill digital savoy dalam mengelola media sebagai upaya adaptasi di era disruptif.

\section{Analisis Data}

Analisis data merupakan sebuah proses dimana mengarah pada eksaminasi sistematis untuk menentukan hubungan antara bagian-bagian dari data yang diperoleh untuk kemudian dilaporkan kepada orang-orang. Bogda dan Biklen dalam Ahmadi (2016: 203) mengemukakan sebagai bahwa annalisis data merupakan suatu proses penyidikan dan pengaturan secara sistematis transkrip wawancara, catatan lapangan, dan material-material lain yang Anda kumpulkan untuk meningkatkan pemahaman Anda sendiri tentang data dan memungkinkan anda untuk mempresentasikan apa yang Anda telah temukan pada orang-orang lain. Analisis meliputi mengerjakan data, mengorganisasinya, membaginya menjadi satuan-satuan yang dapat dikelola, mensistesisnya, mencari pola, menemukan apa yang penting dan apa yang akan dipelajari, dan memutuskan apa yang Anda laporkan.

Analisis data pada penelitian kualitatif sudah dilakukan peneliti sejak pertama kali terjun ke lapangan untuk meneliti sebuah peristiwa atau kasus. Seperti yang 
dikatakan Patton dalam Ahmadi (2016: 203-204) bahwa analisis kualitatif yang dihimpun dari wawancara mendalam dan catatan lapangan berasal dari pertanyaanpertanyaan yang dihasilkan pada proses yang paling awal dalam penelitian, selama pembuatan konseptual, dan fase pertanyaan yang berfokus pada penelitian. Sehingga analisis data dilakukan dalam dua tahap yaitu selama proses pengumpulan data dan pada akhir pengumpulan data.

Analisis data merupakan suatu kegiatan yang sulit sehingga dibutuhkan ketekunan dan kreativitas. Sugiyono (2014: 244) mengemukakan bahwa analisis data adalah proses mencari dan menyusun secara sistematis data yang diperoleh dari hasil wawancara, catatan lapangan, dan dokumentasi, dengan cara mengorganisikan data dalam kategori, menjabarkan ke dalam unit-unit, melakukan sintesa, menyusun ke dalam pola, memilih mana yang penting dan yang akan dipelajari, dan membuat kesimpulan sehingga mudah difahami oleh diri sendiri maupun orang lain.

Dalam hal ini, peneliti melakukan analisis data menggunakan Teknik analisis data di lapangan model Miles and Huberman (1984) dalam Sugiyono (2014: 246). Model Miles and Huberman. Aktivitas dalam analisis data yaitu data reduction, data display, dan coclusion drawing/verification. Langkah dalam aktivitas analisis data model Miles and Huberman sebagai berikut.

\section{Reduksi Data (reduction data)}

Penelitian yang dilakukan di lapangan seringkali menghasilkan jumlah data yang sangat banyak, untuk menyederhanakan data yang terkumpul sesegara mungkin peneliti mereduksi data. Mereduksi data berarti memilah hal-hal yang pokok lalu dirangkum, memfokuskan pada hal-hal yang penting lalu mencari tema dan pola data yang terkumpul. Sehingga data yang telah direduksi lebih jelas dan memudahkan peneliti untuk melakukan pengumpulan data selanjutnya di lapangan.

Peneliti akan dipandu oleh tujuan penelitian yang ingin dicapai dalam mereduksi data, karena tujuan utama dari penelitian kualitatif adalah pada temuan. Reduksi data merupakan proses berfikir sensitif sehingga membutuhkan kecerdasan, keluasan dan kedalaman wawasan yang tinggi dalam melaksanakan penelitian.

\section{Penyajian data (data display)}

Penyajian data merupakan tahap setelah reduksi data. Miles and Huberman dalam Sugiyono (2014: 249) menyatakan "the most frequent form of display data for qualitative research data in the past has been narrative text". Hal yang selalu dilakukan dari penelitian kualitatif yaitu menyajikan data dalam bentuk teks yang bersifat naratif. Miles and Hubermas dalam Sugiyono (2014: 249) menambahkan bahwa "looking at display displays help us to understand what is happening and to do some thing-further analysis or caution on that understanding". Dari penyajian data, peneliti akan lebih mudah untuk memahami apa yang terjadi lalu merencanakan kerja selanjutnya berdasarkan apa yang telah dipahami.

Agar lebih menarik, penyajian data tidak hanya berupa teks, tetapi bisa menggunakan berbagai macam perangkat seperti grafik, matrik, network (jaringan kerja), chart. Peneliti juga perlu menguji apa yang ditemukan pada 
saat memasuki lapangan yang bersifat hipotetik karena fenomena sosial bersifat kompleks dan dinamis sehingga yang ditemukan di lapangan saat masuk dan sedang berlangsung mengalami perkembangan data.

\section{Penarikan kesimpulan dan verifikasi (Conclusion Drawing/verification)}

Penarikan kesimpulan dan verifikasi merupakan langkah terakhir dalam model analisis data Miles and Huberman. Kesimpulan pada penelitian kualitatif memungkinkan untuk menjawab rumusan masalah yang ditentukan sejak awal, tapi mungkin juga tidak karena masalah dan rumusan masalah bersifat sementara dan terus mengalami perkembangan selama penelitian di lapangan. Kesimpulan dalam penelitian kualitatif merupakan temuan baru yang sebelumnya belum pernah ada. Sugiyono (2014: 253) menjelaskan bahwa "Temuan ini dapat berupa deskripsi atau gambaran suatu obyek yang sebelumnya masih remang-remang atau gelap sehingga setelah diteliti menjadi jelas, dapat berupa hubungan kausal atau interaktif, hipotesis atau teori".

Dengan demikian, data yang telah dikumpulkan akan melalui proses untuk menentukan kesimpulan. Dari reduksi data, penyajian data, sampai penentuan kesimpulan dan verifikasi. Jika dalam penarikan kesimpulan telah didukung oleh berbagai macam data yang telah melewati proses dan dirasa cukup mantap serta mendukung kesimpulan, maka penarikan kesimpulan dapat dijadikan sebagai kesimpulan yang kredibel.

\section{Hasil dan Pembahasan}

Perubahan pola komunikasi menjadi dampak dari era disruptif. Hal ini membawa perubahan yang signifikan terutama media yang dahulunya konvensional, sekarang dipenuhi oleh media digital yang ada di setiap scope masyarakat. Dalam penelitian ini ditemukan bahwa Humas Polda D. I. Yogyakarta sebagai salah satu bidang yang memiliki fungsi untuk memberikan informasi ke pada masyarakat di wilayah Polda D. I. Yogyakarta menggunakan strategi komunikasi melalui skill digital savoy yang merupakan sifat atau karakteristik yang akrab dengan teknologi digital. Dalam hal ini, digital savoy dapat diartikan sebagai kemampuan dalam mengelola dan menggunakan teknologi digital itu sendiri.

Temuan penelitian menyokong pendapat Butterick (2014: 153) bahwa strategi komunikasi adalah pendekatan menyeluruh bagi sebuah program dengan instrumen komunikasi dan penjelasan rasional di belakang program taktis dan akan didikte. Kemudian ditentukan oleh persoalan yang muncul dari analisis dan penelitian. Dimana hal ini sesuai dengan pemilihan strategi terhadap persoalan yang dihadapi oleh Humas Polda D. I. Yogyakarta.

Sedangkan Dozier dalam Butterick (2014: 154) mengemukakan bahwa komunikasi menjadi fungsi manajemen strategis, ketika program-program komunikasi bisa membantu mengelola tokoh-tokoh masyarakat yang mempengaruhi visi misi, sasaran, dan tujuan yang telah organisasi atau perusahaan rencanakan. Fungsi manajemen ini, mengaktifkan komunikasi sebagai instrument utama dalam perencanaan perusahaan untuk mencapai tujuan.

Dalam skill digital savvy yang digunakan oleh Humas Polda D. I. Yogyakarta terdapat beberapa aktivitas yang mendukung strategi tersebut. Hal ini terlihat dari data yang diperoleh serta aktivitas staf di Humas Pola D. I. Yogyakarta selama 
observasi berlangsung guna mewujudkan visi misi yang menjadi tujuan utama dalam sebuah strategi komunikasi. Aktivitas yang ditemukan untuk mendukung strategi komunikasi melalui skill digital savoy di era disruptif sebagai berikut.

\section{Pengelolaan Komunikasi Internal melalui WhatsApp}

Penggunakan teknologi digital semakin memperkuat skill digital savvy di ranah tugas Humas Polda D. I. Yogyakarta. Jika dahulu, untuk berbagai macam informasi yang berhubungan dengan satuan kerja akan diadakan rapat dan surat menyurat, maka sekarang segala informasi dapat disampaikan secara cepat melalui tools digital yang tersedia. Bidang humas memiliki grup yang berisikan Direktorat Lalu Lintas Polda D. I. Yogyakarta (ditlantas), Direktorat Pengamanan Obyek Vital (ditpamobvit), Direktorat Polisi Perairan (ditpolair), Satuan Brigade Mobil Polda D. I. Yogyakarta (satbrimob) dan beberapa yang lain yang ada di lingkungan Polda D. I. Yogyakarta serta Polres/Ta dan jajarannya.

Kecepatan arus informasi sangat dibutuhkan di era disruptif karena berbagai macam informasi tidak melihat ruang dan waktu dan segera mungkin dapat diperoleh, agar informasi itu tersampaikan kepada masyarakat. Temuan dari penelitian yang dilakukan relevan terhadap pernyataan yang dikemukakan Kasali (2017: 34) bahwa disrupsi adalah sebuah inovasi. Dari itu, sebagai institusi yang bertugas melayani masyarakat, Humas Polda D. I. Yogyakarta telah menggunakan skill digital savoy sebagai strategi komunikasi di era disruptif.

\section{Pelatihan pengelolaan media digital}

Data yang diperoleh menunjukkan bahwa Humas Polda D. I. Yogyakarta mengikuti perkembangan dan fenomena yang terjadi di masyarakat termasuk maraknya berita hoax. Oleh karena itu, humas Polda D. I. Yogyakarta merupakan institusi yang bertugas untuk melayani masyarakat sehingga dalam pelaksanannya, humas Polda D. I. Yogyakarta juga bertanggungjawab sebagai komunikator publik. Perhatian mengenai skill digital savoy sangat terlihat dari materi yang didapatkan oleh lingkup humas Polri termasuk didalamnya Humas Polda D. I. Yogyakarta. Pelatihan dilakukan untuk menunjang kemampuan dalam bekerja dengan media digital.

\section{Pengelolaan kanal digital lebih aktif}

Media sosial dan website merupakan kanal digital yang dimanfaatkan oleh humas Polda D. I. Yogyakarta dalam menyalurkan informasi kepada publik. Humas Polda D. I. Yogyakarta secara aktif menggunakan kanal digital sebagai saluran komunikasi kepada publik termasuk dalam pemilihan berita yang diberikan.

Humas Polda D. I. Yogyakarta telah memperhatikan aktivitas yang berjalan di media sosial. Berbagai macam pertimbangan dilakukan untuk mengikuti pasar sebagai cara untuk beradaptasi di era disruptif. Pengelolaan media sosial juga telah masuk dalam tahap dimana masing-masing media sosial memiliki 3 admin. Pengelolaan kanal digital telah tertulis dalam surat perintah dan dikelola tidak hanya pada satu bidang, tetapi menjadi tanggungjawab bersama dengan admin masing-masing media sosial di Humas Polda D. I. Yogyakarta. Sehingga dalam prakteknya, staf yang telah mendapatkan pelatihan dapat mengaplikasikan hal yang didapatkan kedalam pengelolaan kanal digital Polda D. I. Yogyakarta. 


\section{Masyarakat dapat berkomunikasi secara langsung}

Skill digital savoy yang digunakan oleh Humas Polda D. I. Yogyakarta mempermudah komunikasi dengan masyarakat sehingga dalam prakteknya masyarakat berani melaporkan suatu kejadian melalui media sosial kepada Humas Polda D. I. Yogyakarta selama dirasa perlu. Hal yang dahulu harus dengan mendatangi kantor, sekarang dengan mudah dapat dikomunikasikan melalui media sosial, walaupun dalam kelanjutannya tidak dapat diproses langsung karena harus melewati alur yang telah disediakan. Dengan skill digital savoy masyarakat bisa merasa lebih dekat dengan institusi kepolisian yang memiliki tugas untuk melayani masyarakat. Terlepas dari bagaimana respon yang diperoleh ketika menghubungi via kanal digital dalam beradaptasi di era disruptif.

\section{Staf Bidang Humas Polda D. I. Yogyakarta memiliki kemampuan yang lebih spesifik}

Kebutuhan Sumber Daya Manusia (SDM) di humas Polda D. I. Yogyakarta semakin spesifik mengikuti perkembangan era. Pada era disruptif, kemampuan yang dimiliki oleh staf semakin spesifik agar pola kerja di ruang lingkup Polda D. I. Yogyakarta khususnya humas Polda D. I. Yogyakarta telah melakukan upaya dalam memilik sumber daya yang lebih spesifik. Jika dahulu penerimaan pegawai dari latar belakang pendidikan kepolisian maupun Pegawai Negeri Sipil (PNS) lebih general. Berbeda dengan sekarang dimana penerimaan dilakukan lebih spesifik sehingga staf yang didapatkan lebih terfokus dalam melakukan fungsi terlebih di Humas Polda D. I. Yogyakarta.

Spesifikasi yang dimiliki oleh staf Humas Polda D. I. Yogyakarta sangat membantu dalam optimalisasi kinerja staf yang lain. Adanya spesifikasi yang dimiliki staf dapat dijadikan sebagi rujukan oleh staf lain sehingga bisa saling membantu, termasuk skill digital savvy dalam pengelolaan kanal digital. Humas Polda D. I. Yogyakarta memiliki staf Bintara Administrasi (Bamin) dan Pembantu Umum (Banum) di setiap Sub bidang Humas Polda D. I. Yogyakarta yang membantu fungsi kerja bidang tersebut. Latar belakang yang diterima berasal dari kejuruan maupun sarjana yang sejalur dengan tugas humas Polda D. I. Yogyakarta. Hal ini menunjukkan bahwa pemilihan staf atau SDM dilakukan secara spesifik sebagai upaya adaptasi di era disruptif.

Aktivitas yang dilakukan oleh Humas Polda D. I. Yogyakarta dalam hal digital savvy sama halnya dengan penelitian yang dilakukan oleh Yuliawati dan Enjang Pera Irawan (2016: 212) mengenai Peran Cyber Public Relations Humas Polri dalam Memberikan Pelayanan Informasi Publik Secara Online dimana hal itu disebutkan sebagai berikut.

Menjalankan berbagai aktivitas kerjanya dibantu atau menggunakan internet sebagai sarana publisitasnya. Melalui cyber public relations, maka praktisi public relations dapat dengan mudah untuk melewati berbagai batasan dan penghalang, serta memudahkan public relations dalam menyampaikan pesan-pesan korporat kepada target, baik itu publik internal maupun publik eksternal, tanpa melalui atau bergantung pada pihak manapun seperti jurnalis atau editor jika didistribusikan di media cetak maupun elektronik.

Sama halnya dengan yang dilakukan oleh Humas Polda D. I. Yogyakarta termasuk pada pemilihan staf yang lebih spesifik guna mendukung strategi komunikasi melalui skill digital savvy. Selain dari aktivitas yang telah diperoleh dalam 
pembahasan ini, ada beberapa kanal digital yang digunakan oleh Humas Polda D. I. Yogyakarta sebagai strategi komunikasi melalui skill digital savoy di era disruptif. Beberapa kanal yang digunakan oleh Humas Polda D. I. Yogyakarta dalam menyampaikan informasi sekaligus berkomunikasi langsung dengan masyarakat sebagai berikut.

\section{Facebook}

Facebook merupakan media sosial yang pertama kali digunakan oleh humas Polda D. I. Yogyakarta. Akun facebook yang bernama @humaspoldajogja pertama kali beroperasi pada tanggal 30 november 2015 dan dalam perkembangnnya hingga per mei 2018 telah di sukai oleh masyarakat cyberspace facebook sebanyak 4.964 orang.

\section{Twitter}

Humas Polda D. I. Yogyakarta pertama kali menggunakan media sosial twitter pada 9 januari 2017 dengan nama @PoldaJogja. Perkembangan sampai 22 mei 2018 telah mengeluarkan tweet sebanyak 6.228 kali, mengikuti sebanyak 86 akun, dengan pengikuti sebanyak 5.631 orang.

\section{Instagram}

Humas Polda D. I. Yogyakarta pertama kali menggunakan media sosial Instagram secara resmi pada tanggal 9 januari 2017 dan dalam perkembangannya hingga 22 mei 2018 akun instagram dengan nama @poldajogja memiliki pengikuti sebanyak 36.131 akun, mengikuti 104 akun, serta kiriman sebanyak 5.947 postingan.

\section{YouTube}

Media sosial youtube termasuk kanal digital yang baru digunakan oleh humas Polda D. I. Yogyakarta. Channel youtube yang bernama Humas Polda DIY memulai postingan pertama pada tanggal 17 Mei 2017 dan dalam perkembangannya sampai tanggal 22 mei 2018 memiliki 144 subscriber dengan jumlah 35 video.

\section{Website}

Website merupakan salah satu kanal wajib yang harus dimiliki oleh institusi pemerintahan termasuk Polda D. I. Yogyakarta. Humas Polda D. I. Yogyakarta mengelola 2 website Polda D. I. Yogyakarta sejak tahun 2015 yaitu www.jogja.polri.go.id dan tribratanews.jogja.polri.go.id.

Hasil penelitian didapatkan bahwa Humas Polda D. I. Yogyakarta menggunakan berbagai macam kanal digital sebagai cara agar informasi yang disampaikan kepada publik dapat diterima dengan baik. Selain itu, pemenuhan konten yang disiapkan semakin mempertegas bahwa skill digital savvy pada humas Polda D. I. Yogyakarta benar-benar dilakukan agar setiap kanal digital bisa menyesuaikan berdasarkan karakteristik masing-masing dan menyesuaikan dengan kemauan masyarakat terlebih di era disruptif.

Laksamana (2018: 45) menjelaskan bahwa kanal digital semua yang mencakup digitalisasi mulai dari media sosial seperti Twitter, LinkedIn, Youtube, Facebook, LINE Today, social messaging seperti WhatsApp, Line, Blackberry Messanger (BBM), hingga media online seperti portal berita dan website resmi. Dengan demikian, skill digital 
savoy merujuk pada penggunaan kanal digital termasuk konten dan cara penggunannya guna memberikan informasi. Termasuk pada bagian strategi komunikasi untuk beradaptasi di era disruptif.

Sementara itu, Kartikasari (2017: 4-7) menyatakan publik dimanjakan oleh keberlimpahan informasi, yang dengan mudah bisa didapatkan melalui internet, sehingga mereka sekarang benar-benar menjadi raja. Mereka yang menentukan dan memilih sehingga mereka pula yang lebih banyak mempengaruhi semua jenis tools, bukan sebaliknya sebagaimana paradigma era lama. Hal ini menyebabkan untuk memahami public journey dengan sangat baik.

Terlepas dari kegiatan Humas Polda D. I. Yogyakarta melalui skill digital savvy di era disruptif, terdapat kelebihan dan kekurangan yang dihadapi. Kelebihan dan kekurangan sebagai berikut.

1. Kelebihan strategi komunikasi humas Polda D. I. Yogyakarta melalui skill digital savoy di era disruptif

a. Alur komunikasi humas Polda D. I. Yogyakarta menjadi lebih sangkil dan mangkus dengan adanya skill digital savvy dipertegas dari pola komunikasi yang dapat melalui grup WhatssApp. Sehingga segala informasi yang memerlukan kecepatan dapat tersampaikan dan diselesaikan dengan tepat.

b. Penyajian informasi melalui kanal digital lebih terorganisir dan lebih menarik karena adanya pelatihan untuk meningkatkan skill digital savoy di lingkup humas Polri termasuk humas Polda D. I. Yogyakarta.

c. Masyarakat dengan mudah memperoleh informasi mengenai Polda D. I. Yogyakarta. Hal ini dipertegas dengan kanal digital yang menyajikan konten menarik yang sesuai karakteristik masing-masing media sosial yang lebih aktif.

d. Masyarakat lebih mudah terhubung dengan institusi Polda D. I. Yogyakarta yang dipertegas dengan informasi yang secara langsung diterima serta masyarakat yang bisa melakukan direct message (DM) ke kanal digital yang selanjutkan akan diarahkan oleh admin.

e. Staf yang ada di humas Polda D. I. Yogyakarta sesuai dengan bidangnya dipertegas dengan adanya spesifikasi yang jelas dalam penerimaan pegawai Polri termasuk Polda D. I. Yogyakarta sebagai upaya adaptasi di era disruptif.

2. Kekurangan strategi komunikasi humas Polda D. I. Yogyakarta melalui skill digital savoy di era disruptif

a. Kurangnya staf di humas Polda D. I. Yogyakarta sehingga dalam pengelolaan kanal digital masih terbatas.

b. Belum ada sub bidang multimedia yang memiliki fokus pada digital savoy sehingga dalam pengelolaan informasi tidak terfokus pada 1 sub bidang, berbeda dengan divisi humas Polri yang telah berfokus di bidang multimedia. 
Dari penelitian ini terdapat hal mengenai kelebihan strategi komunikasi humas Polda D. I. Yogyakarta melalui skill digital savoy yang mampu meningkatkan komunikasi antara staf sehingga pola komunikasi yang terbentuk lebih solid. Akan tetapi, kekurangan jumlah staf tetap mempengaruhi kinerja humas Polda D. I. Yogyakarta. Khusus pada belum adanya sub bidang multimedia yang khusus pada pengelolaan kanal digital, hal ini mempengaruhi kerja sehingga tidak optimal dalam mengingat berbagai macam perubahan yang dapat terjadi di era disruptif.

Sama halnya dengan penelitian yang dilakukan oleh Brionesa, Kuch, Liu, \& Jin (2011) dengan judul "Keeping up with the digital age: How the American Red Cross uses social media to build relationships" bahwa Practicing public relations through social media is effective and necessary in the emerging digital age, as shown through the Red Cross' development of a two-way dialogue with younger constituents, the media, and the community. This two-way dialogue has been accomplished primarily through Twitter and Facebook, with barriers such as lack of staff and time, and opportunities to improve National Headquarters and local chapter relations.

Dari hal tersebut bahwa, praktek yang dilakukan oleh Humas melalui media sosial itu efektif dan perlu dilakukan dalam era digital yang baru hadir seperti saat ini, seperti yang diperlihatkan oleh Palang Merah Amerika dalam mengelola komunikasi dua arah kepada khalayak pemula, media, dan masyarakat. Komunikasi dua arah telah tercapai melalui twitter dan facebook, walaupun ada hambatan seperti kurangnya staf dan waktu, serta pengembangan markas dan hubungan wilayah lokal.

Media sosial sebagai salah satu kanal digital yang merupakan bagian dari era disruptif perlu dimanfaatkan melalui skill digital savvy. Hal ini telah dilakukan oleh Humas Polda D. I. Yogyakarta bahkan menggunakan lebih banyak kanal digital dengan karakteristik yang berbeda. Walaupun pada prakteknya ada kekurangan dari belum adanya bidang multimedia yang benar-benar fokus pada pengelolaan skill digital savvy. Dengan demikian, penelitian ini mendeskripsikan bahwa Polda D. I. Yogyakarta menggunakan strategi komunikasi melalui skill digital savvy dengan segala aktivitas yang mendukung di era disruptif.

\section{Kesimpulan dan Saran}

\section{Kesimpulan}

Berdasarkan penelitian dan pembahasan yang telah dilaksanakan, maka dapat diambil kesimpulan sebagai berikut:

1. Strategi komunikasi humas Polda D. I. Yogyakarta melalui skill digital savoy di era disruptif yaitu:

a. Pengelolaan Komunikasi Internal melalui WhatsApp di humas Polda D. I. Yogyakarta menjadikan pola komunikasi lebih sangkil dan mangkus terlebih dalam penanganan informasi lebih cepat.

b. Pelatihan pengelolaan media digital dengan materi yang lengkap dan fokus pada penguatan skill digital savoy sebagai upaya humas Polda D. I. Yogyakarta beradaptasi di era disruptif. 
c. Pengelolaan kanal digital yang aktif oleh humas Polda D. I. Yogyakarta sebagai saluran komunikasi kepada publik termasuk dalam pemilihan berita yang diberikan dengan berbagai macam pertimbangan dilakukan untuk mengikuti pasar sebagai cara untuk beradaptasi di era disruptif.

d. Masyarakat dapat berkomunikasi secara langsung melalui media sosial kepada humas Polda D. I. Yogyakarta selama dirasa perlu, walaupun dalam kelanjutannya tidak dapat diproses langsung karena harus melewati alur yang telah disediakan.

e. Staf bidang humas Polda D. I. Yogyakarta memiliki kemampuan yang lebih spesifik mengikuti perkembangan era sehingga dalam menjalankan tugas humas semakin optimal.

2. Kanal Digital yang digunakan dalam strategi komunikasi humas Polda D. I. Yogyakarta melalui skill digital savoy di era disruptif yaitu, Facebook yang bernama @humaspoldajogja, Twitter yang bernama @PoldaJogja,Instagram yang bernama @poldajogja, Youtube dengan channel yang bernama Humas Polda DIY, Website dengan domain www.jogja.polri.go.id yang berisi Polda D. I. Yogyakarta secara umum dan tribratanews.jogja.polri.go.id yang khusus untuk berita

3. Kelebihan dan kekurangan dalam strategi komunikasi humas Polda D. I. Yogyakarta melalui skill digital savoy di era disruptif

a. Kelebihan yang diperoleh yaitu alur komunikasi humas Polda D. I. Yogyakarta menjadi lebih sangkil dan mangkus, penyajian informasi melalui kanal digital lebih terorganisir dan lebih menarik, masyarakat dengan mudah memperoleh informasi mengenai Polda D. I. Yogyakarta, dan masyarakat lebih mudah terhubung dengan institusi Polda D. I. Yogyakarta, serta staf yang ada di humas Polda D. I. Yogyakarta sesuai dengan bidangnya.

b. Kekurangannya adalah kurangnya staf di humas Polda D. I. Yogyakarta sehingga dalam pengelolaan kanal digital masih terbatas dan belum ada sub bidang multimedia yang memiliki fokus pada digital savvy sehingga dalam pengelolaan informasi tidak terfokus pada 1 sub bidang.

Saran

Berdasarkan pada rumusan masalah dan hasil penelitian serta pembahasan yang telah dilaksanakan, maka dikemukakan saran sebagai berikut.

1. Dalam rangka mengoptimalisasi fungsi kerja pada bidang humas Polda D. I. Yogyakarta disarankan untuk menambah staf yang tentunya sesuai dengan spesifikasi dan bidangnya agar mampu melaksanakan tugas khususnya pengelolaan kanal digital. Mengingat jumlah kanal digital serta pengelolaan konten perlu diperhatikan sehingga humas Polda D. I. Yogyakarta dapat beradaptasi di era disruptif.

2. Untuk bidang Humas Polda D. I. Yogyakarta sebaiknya membentuk sub bidang multimedia agar segala hal terkait pengelolaan kanal digital dapat terfokus pada satu sub bidang. Selain kanal digital, sub bidang multimedia 
dapat menjadi bank data agar kedepannya data yang sudah ada lebih terintegritas.

\section{DAFTAR PUSTAKA}

Ahmadi, R. (2016). Metodologi Penelitian Kualitatif. Yogyakarta: Ar-Ruzz Media.

Airlanga, M. (2018). Indonesia Digital Landscape 2018 GDP Venture. Diakses dari https://www.slideshare.net/thinkfresh1/indonesia-digital-landscape-2018-gdp-venture pada tanggal 2 April 2018 pukul 02.46 WIB.

Andriadi, F. (2016). Demokrasi di Tangan Netizen. Jakarta: RMBOOKS.

Briones, Rowena L., Kuch, Beth., Liu, Brooke Fisher., et ai (2011). Keeping Up with the Digital Age: How the American Red Cross Uses Social Media to Build Relationships. Public Relations Review, 37, 37-43.

Butterick, K, (2014). Pengantar Public Relations: Teori dan Praktik. Jakarta: PT Raja Grafindo Persada.

Hargittai, E. \& Shaw, A. (2013). Digitally Savvy Citizenship: the Role of Internet Skills and Engagement in Young Adults' Political Participation around the 2008 Presidential Election. Broadcasting \& Electronic Media, 57, 115-134.

Hastasari, C., Suranto, Setiawan, B. (2016) Strategi Komunikasi Guru SMA Islam Terpadu dalam Menghasilkan Siswa yang Unggul. Informasi: Kajian Ilmu Komunikasi, 46, 129-142.

Ishaq, R.E. (2017). Public Relations: Teori dan Praktik Edisi Revisi. Malang: Intrans Publishing.

Kartikasari, N. (2017). Viral: Gebrakan Kekinian Public Relations di Era Digital. Jakarta: PT Gramedia Pustaka Utama.

Kasali, R. (2017). Disruption: tak Ada yang tak Bisa Berubah Sebelum dihadapi Motivasi Saja tidak Cukup. Jakarta: PT Gramedia Pustaka Utama.

Laksamana, A. (2018). Public Relations in the Age of Disruption. Yogyakarta: PT Bentang Pustaka.

Mahfudz, H. (2017). Merengkuh Generasi Millenial. Diakses dari http://www.prindonesia.co/detail/675/Merengkuh-Generasi-Millennial pada tanggal 2 April 2018 pukul 02.35 WIB.

Mulyana, D. (2013). Ilmu Komunikasi Suatu Pengantar. Bandung: PT Remaja Rosdakarya.

Nizak, Z. (2013). Analisis SWOT untuk Menentukan Strategi Kompetitif. Ekbis: Analisis, Prediksi dan Informasi, 9, 462-488.

POLDA D. I. Yogyakarta, BID HUMAS, diakses dari https://jogja.polri.go.id/website/?page_id=2168 pada tanggal 17 April 2018 pukul 02.43 WIB.

POLRI, Program Prioritas, diakses dari https://promoter.polri.go.id pada tanggal 12 Maret 2018 pukul 01.02 WIB.

Ruliana, P. (2014). Komunikasi Organisasi:Teori dan Studi Kasus. Depok: PT Rajagrafindo Persada. 
Sugiyono. (2014). Metode Penelitian Kuantitatif Kualitatif dan RED. Bandung: Alfabeta.

Suranto, Aw. (2011). Komunikasi Interpersonal. Yogyakarta: Graha Ilmu.

Yuliawati, Irawan, E.P. (2016). Peran Cyber Public Relations Humas Polri dalam Memberikan Pelayanan Informasi Publik secara Online (Studi Deskriptif tentang Penerapan Peran Cyber Public Relations dalam Mengelola website humas.polri.go.id sebagai implementasi Undang-undang Keterbukaan Informasi Publik). Politikom Indonesiana: Kajian Ilmu Pemerintahan, Ilmu Politik, dan Ilmu Komunikasi, 1, 208-220. 